University of Nebraska - Lincoln

DigitalCommons@University of Nebraska - Lincoln

2-1-2021

\title{
Nebraska Corn Basis Response to Economic Shutdown
}

\author{
Austin Harthoorn \\ United States Department of Agriculture, Agricultural Research Service, austinharthoorn@gmail.com \\ Cory Walters \\ University of Nebraska-Lincoln, cwalters7@unl.edu \\ Jessica J. Groskopf \\ University of Nebraska-Lincoln, JJohnson@unl.edu
}

Follow this and additional works at: https://digitalcommons.unl.edu/ageconfarmmgmt

Part of the Agribusiness Commons, Entrepreneurial and Small Business Operations Commons, Management Information Systems Commons, Other Business Commons, and the Other Economics Commons

Harthoorn, Austin; Walters, Cory; and Groskopf, Jessica J., "Nebraska Corn Basis Response to Economic Shutdown" (2021). Extension Farm and Ranch Management. 58.

https://digitalcommons.unl.edu/ageconfarmmgmt/58

This Article is brought to you for free and open access by the Agricultural Economics Department at DigitalCommons@University of Nebraska - Lincoln. It has been accepted for inclusion in Extension Farm and Ranch Management by an authorized administrator of DigitalCommons@University of Nebraska - Lincoln. 


\section{Nebraska Corn Basis Response to Economic Shutdown}

\section{By Austin Harthoorn, Cory Walters and Jessica Groskopf}

Feb. 1, 2021

The events of 2020 caused large fluctuations in the Nebraska corn market, with cash prices reaching levels rarely observed. From cash prices in some areas approaching $\$ 2.50$ following planting, to bids around $\$ 4.50$ immediately following harvest, 2020 certainly had its up and downs. This variation in cash price is a result of changes in both futures price and basis. In this article, we will look back at the influence this year's events have had specifically on Nebraska corn basis.

The objective of this article is to evaluate how Nebraska corn basis evolved through this past year's economic events. We hope growers update their commodity price marketing decision framework as this past year exposed levels prices can reach - an important factor to consider when farm survival is on the line.

Nebraska crop producers started the year under seemingly normal circumstances with reasonable stocks and prices, both within the range of recent past experiences. The introduction and growth of COVID-19 throughout the spring triggered a series of events that dramatically altered the pricing environment. COVID-19 triggered a massive economic shutdown, meeting the nation's corn producers with declining commodity prices. As we know, corn is widely used across our economic system, with the largest exposure being in the fuel, export, and domestic feed markets.

Nebraska average corn basis from fall 2016 to fall 2019 is presented in Figure 1, which starts at week 37, around the time when the December contract becomes the nearby futures contract.

Figure 1: Nebraska Average Corn Basis

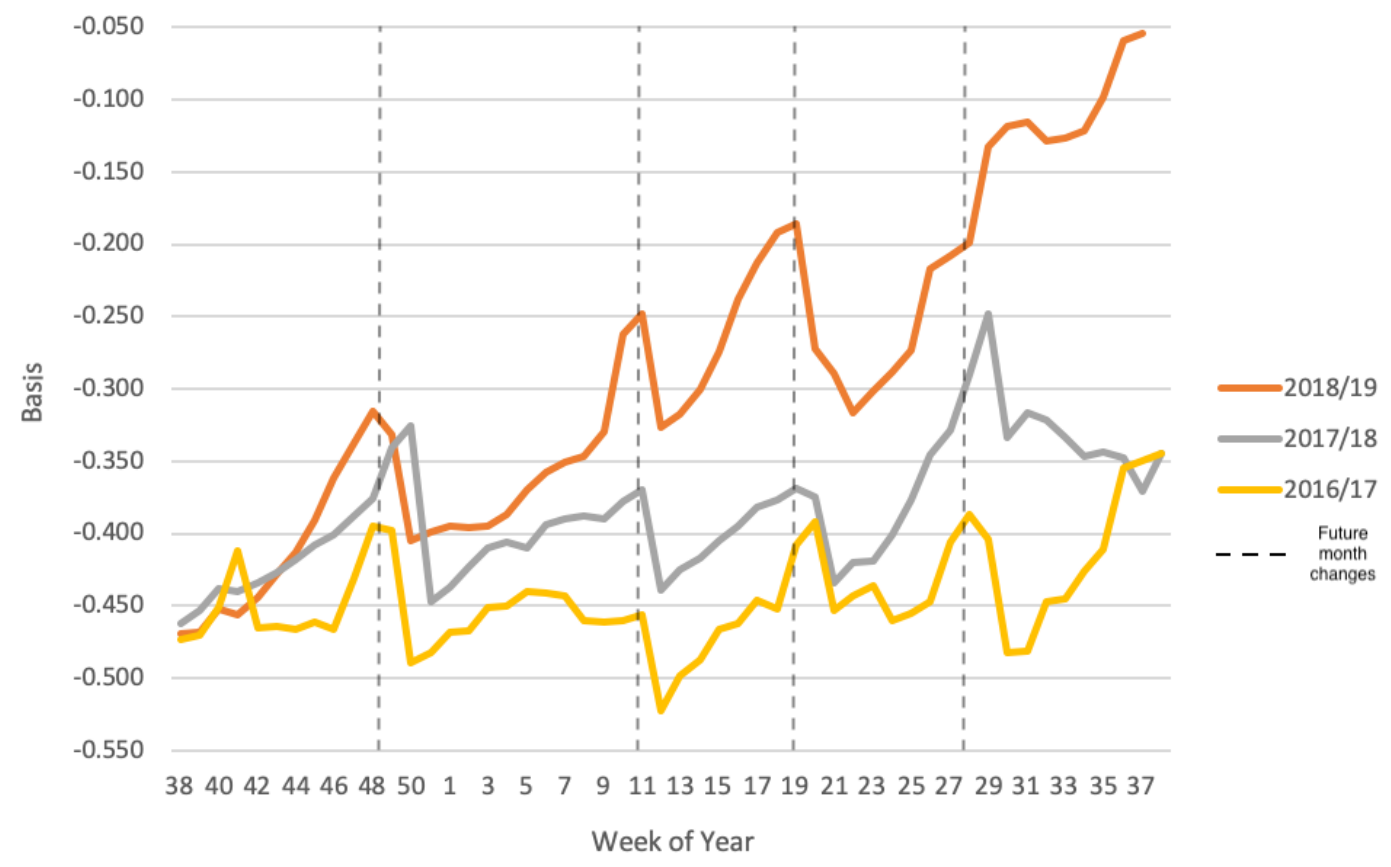


In the past three years, Nebraska average basis began the crop year at around $-\$ 0.46$ under. Basis then varied throughout the storage period (post-harvest) with declines occurring when rolling from one futures contract to another, as can been seen in Figure 1. Notably, the 2018/19 crop year ended with a stronger basis than had been recently experienced. As a result, the 2019/20 crop year also began with the same strong basis. Figure 2 includes the addition of the 2019/20 crop year to the previous 3 crop years.

Figure 2: Nebraska Average Corn Basis

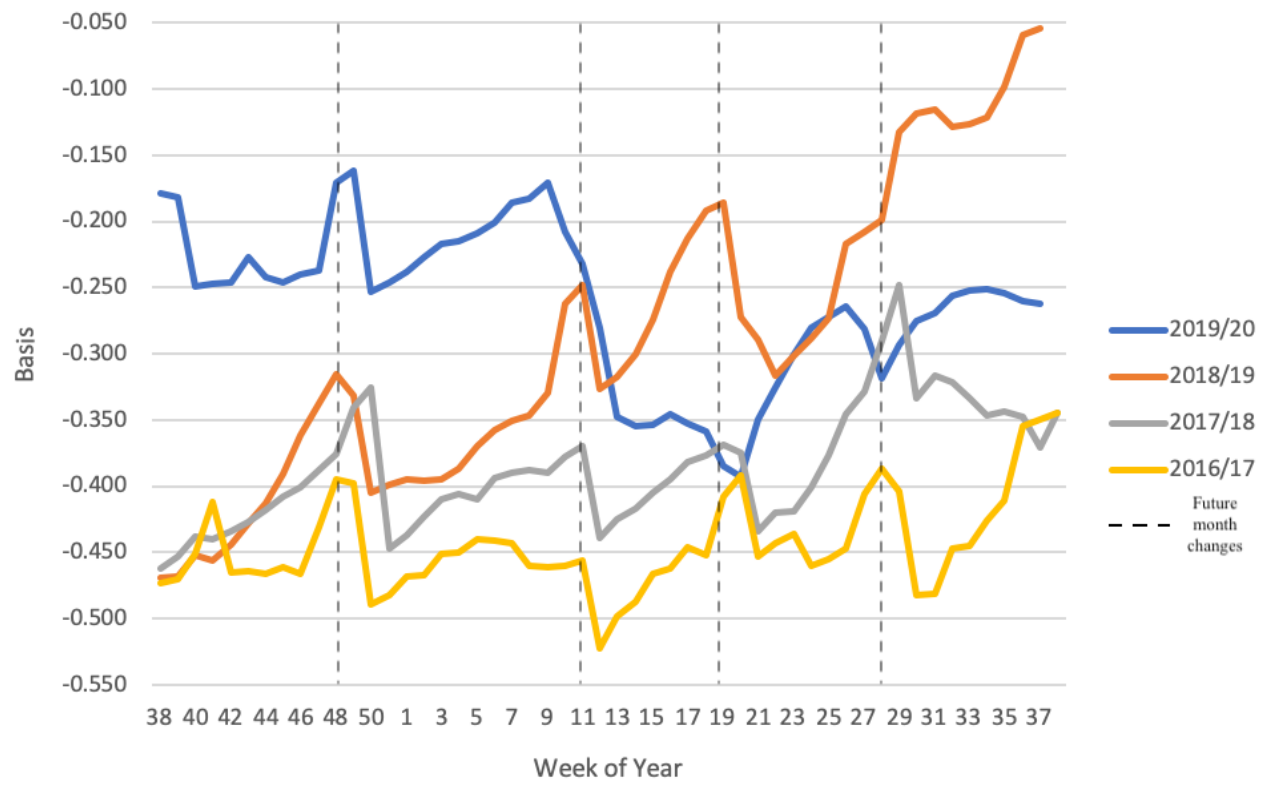

The 2019/20 Nebraska average basis followed a similar pattern to the previous three crop years, with a decline in basis when rolling from December corn futures to March. However, after week nine, a few weeks before buyers typically roll future months, basis began to decline. This appears to be the beginning of the influence of the economic shutdown on corn basis. Nebraska corn basis dropped from - $\$ 0.17$ in week 9 to $-\$ 0.35$ in week 13. This decline in corn basis continued until week 20, where Nebraska average basis reached $-\$ 0.40$. As corn futures rolled from March to May during this time, it's impossible to place the entirety of the decline in basis on the economic shutdown, although it seems evident the shutdown's impact was much greater than the expected decline from rolling future months. Also notable is the fact that since basis entered the crop year narrower than in previous years, the drop didn't cause record basis lows to be experienced. However, recall that during this same time, corn futures were also declining, thereby putting the producer in a precarious position with lower futures and lower basis levels. Toward the end of the crop year, some of this pressure was relieved as basis rebounded about $\$ .0 .15$ from the lows in week 20.

\section{Regional Basis Changes}

Basis can vary regionally, and we can investigate the impact of the economic shutdown on the regional level. This past summer, the Agricultural Marketing Service (AMS) revised their Nebraska cash commodity prices report, now reporting by Crop Reporting District (CRD) rather than by individual 
location. To evaluate basis at the regional level, will be look for changes within each CRD. Nebraska's eight CRDs are shown in Figure 3. Note the CRD 20 commodity report does not include corn.

Figure 3: Nebraska Crop Reporting Districts (CRDs)

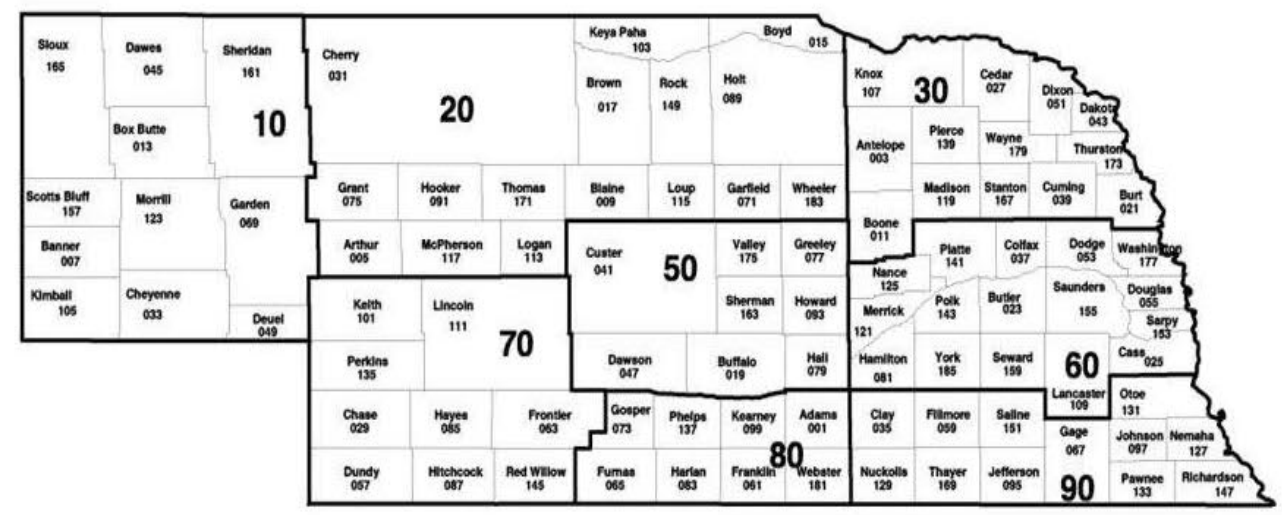

We present the 2019/20 corn basis by CRD in Figure 4. From this figure, all CRDs in Nebraska experienced a significant decline in basis starting around week 10. However, the outcomes among each CRD following the economic shutdown differ. For example, CRD 10 entered week 10 with the widest average basis value. However, by the end of the crop year, basis in the area was the narrowest.

Alternatively, CRD 30 entered week 10 with the narrowest basis among the CRDs and ended the crop year with the widest basis. Thus, it is apparent the economic shutdown caused all locations in Nebraska to widen their basis, with the outcome following the shutdown being specific to each CRD. Some CRDs are offering a narrower basis than before, while some are offering a wider basis. Quite possibly, production factors in those CRDs are influencing the local basis values.

Figure 4: 2019/2020 Nebraska Basis by Crop Reporting District

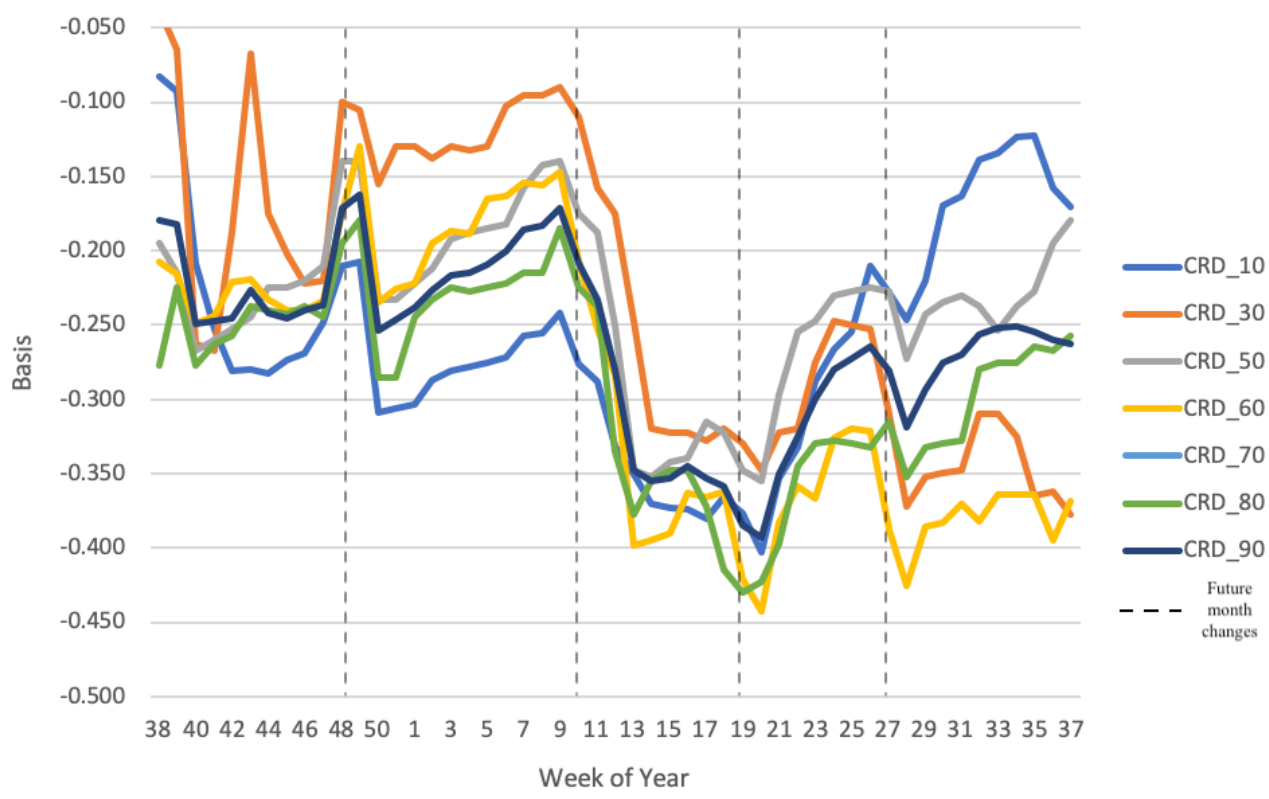


The events of this past year revealed where commodity prices can go. While we do not want prices decline to this area again, we must be cognizant that they can (and will again, someday). Financial and mental costs of putting little to no weight on rare events can be deadly to farm finances. We hope readers revise their risk management plans to incorporate rare pricing paths when deciding how to manage future, uncertain prices. A decent basis bid for new crop corn may be worth taking a position on a percent of expected production as you reduce exposure to rare events. Higher than normal futures prices may also be worth taking a position on a percent of expected production. As we venture into a new unknown future, hope that your first sale is your worst, knowing that you are protecting the farm from financial hardship if it becomes your best.

Austin Harthoorn is a Master of Science student in the Department of Agricultural Economics. Cory Walters is an associate professor and grain marketing specialist in the Department of Agricultural Economics. Jessica Groskopf is an extension educator and agricultural economist for the panhandle region. 